\title{
A regionális és a vállalati kultúra kölcsönhatásának vizsgálata
}

\section{A study of the interaction between corporate and regional culture}

\section{KONCZOSNÉ SZOMBATHELYI MÁRTA}

KONCZOSNÉ SZOMBATHELYI Márta: egyetemi docens, Széchenyi István Egyetem, Marketing és Menedzsment Tanszék, Győr; kszm@sze.hu

KULCSSZAVAK: beágyazottság, elkötelezettség, vállalati kultúra, regionális kultúra

ABSZTRAKT: A Corporate Culture and Regional Embeddedness (CURE) (Vállalati kultúra és regionális beágyazódás) projekt (2007-2009) célja volt a regionális és a vállalati kultúra közti kölcsönhatás, a kulturális változások folyamatának tanulmányozása, továbbá annak a megválaszolása, hogyan tudja az európai régiók kulturális sokszínűsége növelni a vállalatok versenyképességét.

A kutatás hat európai ország (Ausztria, Németország, Magyarország, Hollandia, Svájc, Egyesült Királyság) hét régiójában zajlott. Régiónként 30, összesen 210 vállalatot vizsgáltunk, a vállalat regionális beágyazódása, továbbá a régió és a vállalat kölcsönös egymásra hatása szempontjából. A vizsgálat módszerei a vállalatok vezetőivel készített mélyinterjúk, továbbá a stakeholderekkel folytatott fókuszcsoportos interjúk voltak.

A projekt feltárta a regionális és a vállalati kultúra közti kölcsönhatást és a kölcsönhatásból következő változási folyamatot: egyrészt, hogy hogyan befolyásolja a regionális fejlődést a régióban múködő vállalatok kultúrája, másrészt, hogy hogyan befolyásolja a régióban működő vállalatokat a regionális kultúra. Az erős regionális kultúra képes az innováció és a fellendülés számára megfelelő feltételeket teremteni. A kutatás rámutatott a multinacionális vállalatok pozitív, régiókra gyakorolt hatására, valamint a régióknak - különösen a nyílt innovációs területeknek - e vállalatokra gyakorolt pozitív hatására. A vizsgálat négy területre fókuszált, amelyek vizsgálata elősegíti a beágyazottság jobb megértését. Ezek a területek az innováció, a humán erőforrás, a gazdasági értelemben vett fenntarthatóság és az életminőség.

Márta KONCZOSNÉ SZOMBATHELYI: associate professor, Department of Marketing and Management, Széchenyi István University, Győr; kszm@sze.hu

KEYWORDS: embeddedness, engagement, corporate culture, regional culture, interaction

ABSTRACT: This paper was written on the basis of a cross-border research, CURE. The Corporate Culture and Regional Embeddedness research project was conducted between 2007 and 2009. The major objective of the project was to produce an empirical analysis to study the interaction between corporate and regional culture, and the change processes resulting from this

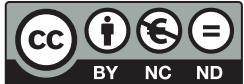


interaction. How the vital cultural diversity in European regions can enhance corporate competitiveness was the core question of the international, three-year research project.

The research was carried out in six European countries (Austria, Germany, Hungary, the Netherlands, Switzerland, and the UK) and their seven regions, by conducting 30-30 interviews with the owner/top managers among 30-30 companies and focus group research among their main stakeholders in each region.

Through a multidisciplinary study, the CURE project investigated and explored on the one hand how regional development is influenced by company cultures and, on the other hand, how companies are influenced by regional cultures. Strong regional cultures can help to create conditions under which innovation and prosperity can flourish. The CURE project emphasised that regional development can also be positively influenced by global corporate cultures. Also, companies can benefit from tapping into different regional cultures, especially in an era of "open innovation". The following fields of investigation were defined to enable the analysis of embeddedness: innovation, human resources, sustainability in ecological terms and quality of life.

\section{Bevezetés}

Európa egyik lehetősége a sokszínű regionális kultúrákban rejlik. A 2007. január és 2009. december között zajlott, az EU 6. keretprogramja által támogatott Corporate Culture and Regional Embeddedness (CURE) (Vállalati kultúra és regionális beágyazódás) projekt hat ország hét régióját kutatta. Alapvető célja volt annak vizsgálata, miképp növeli a kulturális sokszínűség az ott mủködő vállalatok versenyelőnyét. A három évig tartó vizsgálat ezen belül kitért a regionális és a szervezeti kultúrák egymásra hatására, egymást befolyásoló tényezőire, a dinamikus kulturális kölcsönhatásra, a vállalatok regionális beágyazottságára, valamint a beágyazottság hiányának felderítésére. A fókuszba állított négy terület a következő volt: innováció, életminőség, humán erőforrás, környezeti felelősség.

A CURE nemzetközi kutatócsoportjai hat ország hét régiójából egy-egy kutatóintézetnek vagy egyetemnek a munkatársai. Ezen országok és régiók a következők: Nagy-Britannia (Wales/Cardiff), Németország: (Kelet-Vesztfália/Lippe; Délnyugat-Brandenburg), Hollandia (Délkelet-Hollandia), Svájc (Bázel környéke/Olten), Ausztria (Stájerország/Bécs), Magyarország (Győr környéke).

A kutatás módszerei a következők voltak: 30-30 vállalat vezetőjével készített interjú, továbbá a régióban jelen levő stakeholderekkel folytatott fókuszcsoportos beszélgetés. A közös feladatok segítésére rendszeresen workshopokat szervezett a projektvezető német kutatócsoport.

A különböző kulturális beállitódások összjátéka, a stratégiai dilemmák közti egyensúlyozás, a hálózatok társadalmi-kulturális háttere, valamint a stakeholdereknek a régiók és a vállalatok iránti elkötelezettsége olyan kulcsfontosságú tényezők, amelyek vizsgálata lehetővé teszi, hogy megtudjuk, hova tartanak a régiók és az ott müködő vállalatok.

A magyar vonatkozású eredményeket hazai és nemzetközi konferenciakiadványokban már korábban bemutattam (Konczosné 2009a, 2009b, 2009c, 
2010a, 2010b, 2011; Konczosné, Losoncz, Józsa 2010). Ez a tanulmány a teljes projekt hét régióra vonatkozó anyagát ismerteti.

\section{Elméleti háttér}

A menedzsmentelméletek évszázadokig „kultúramentesek” voltak. A 19. század második felétől kezdtek a kultúrára úgy tekinteni, mint a gazdaság szempontjából fontos tényezőre, sőt az 1980-as éveket a „kultúra évtizedének” nevezik (Cameron, Quinn 2006). A határokon átnyúló régiók, az ezekben müködő kis- és középvállalatok kulturális szempontú kutatása is széles körüvé vált (például Ablonczyné Mihályka, Tompos 2011a, 2011b; Szőke, Ablonczyné Mihályka 2011; Tompos, Ablonczyné Mihályka 2011).

Az elmúlt években egyre nagyobb érdeklődés mutatkozott a regionális kutatók részéről is (Rechnitzer, Lengyel 2004) aziránt, hogy a kultúra milyen szerepet tölt be a gazdaság vitalitásában, valamint a régió gazdasági innovációjának dinamikájában (Gertler 2004; Tura, Harmaakorpi 2005). Ezek a kulturális különbségek megjelennek az egyének szintjén is (Huszka 2010, 2012). A kulturális, intézményi és társadalmi tényezőket az ipari körzetek szakirodalma úgy említi, mint a gazdasági fejlődéshez és az innovatív miliőhöz nélkülözhetetlen eszközöket (Asheim 2000; Crevoisier 2004; Kebir, Crevoisier 2007).

Napjainkban emellett a magas technológiai igényü klaszterekről és a tudásintenzív iparágakról (Cooke 2002; Keeble, Wilkinson 2000), a regionális innovációs módszerekről (Cooke, Boekholt, Tödtling 2000; Cooke, Heidenreich, Braczyk 2004; Tödtling, Trippl 2007), a tanuló régiókról (Boekma, Morgan, Bakkers, Rutten 2000), továbbá a kreatív osztály megközelítéséről (Florida 2005) olvashatunk a tanulmányokban.

A regionális tudományok kulturális fordulatát számos kritika érte. Ilyen például a kultúrák és az intézmények instrumentális magyarázata, valamint a kulturális tényezők megfogalmazásának és gyakorlati vizsgálatának problémája (Martin, Sunley 2003; Rodriguez-Pose 2001). Mindazonáltal a kultúra, az intézmények és a társadalmi tőke továbbra is kiemelt kutatási területek (Tödtling, Trippl 2007).

A hagyományos szervezeti kultúra modelljeit szintén kritika érte. Például Hofstede, Hofstede és Minkov (2004) modelljét merev, statikus volta miatt bírálják, amely a kultúrát változatlan entitáskent kezeli. Így ez kevésbé alkalmas dinamikus kulturális kölcsönhatások vizsgálatára, holott magát az időt kulturális tényezőként Bond a modell részévé tette (Süle 2010). A dilemmamegközelítés viszont (HampdenTurner, Trompenaars 2000) elfogadja a kultúrák összetettségét, a dinamikát és a külső környezet paradox igényének hatását. A CURE projekt ez utóbbi megközelítést, a dinamikus kultúra modelljét alkalmazta. A szervezeti kultúrára olyan mintaként tekintett, amellyel a szervezetek kifejezik a különböző értékekhez való viszonyukat. 
A vállalatokra ható külső tényezők (tudáshálózatok, innováció), valamint a társadalmi felelősségvállalás (jó polgárság) irodalma széles körü. Ugyanakkor hiányzik a vállalatok regionális elköteleződésének, régióba való beágyazottságának elemzése, például a szervezeti kultúra és a regionális kultúra kölcsönhatásainak vizsgálata. A CURE projekt és e tanulmány ezekre kereste a választ.

A kutatás elején hét elméleti összefoglaló készült, amelyek célja a vállalati és a regionális kultúra fogalmának, valamint e kultúrák kölcsönhatásának tisztázása volt.

Az első elméleti munka (Tödtling, Trippl 2007) összefoglalta a regionális innovációs kultúra kulcsfontosságú elméleteit. A szerzők szerint egyre nagyobb hangsúly helyeződik a régiók innovációs eredményeinek társadalmi-kulturális hátterére, jelezve ezzel, hogy az elmúlt néhány évben „kulturális fordulat” következett be a regionális tudományokban. A tanulmány összehasonlította a különböző iskolák gondolatait a régiók innovációs kultúrájáról.

A második elméleti anyag írói (David, Gärtner, Rehfeld 2007) hangsúlyozták a regionális sajátosságok szerepét a régiók sikerességében. Értelmezésük szerint a regionális „másság” olyan forradalmi folyamat eredménye, amelyet számos szereplő tevékenysége hoz létre. Ezt támogathatja ugyan regionális stratégia, de valójában a folyamat maga nem szervezhető. Így számos regionális kultúra él egymás mellett, egy időben, de ezek egyedi pályákat írnak le.

Clifton (2007) a harmadik elméleti összefoglalásban azt hangsúlyozta, hogy a helyi kultúrák a domináns világtermékek, a kapitalizmus különböző formái és a domináns regionális innovációs rendszerek kereszteződésében helyezkednek el. A tanulmány az üzleti és a regionális innovációs kultúrák, továbbá a vállalatok széles körü tipológiáját adja.

A regionális kultúrát a szervezetek és a régió közti állandó kölcsönhatások határozzák meg. Pekruhl, Minning és Dörhöfer (2008) alkalmazták munkájukban (negyedik elméleti anyag) a „személyzet mint szállítójármű” kifejezést. Ez értelmezésük szerint azt jelenti, hogy a szervezet dolgozói közvetítenek a régió és a szervezetek, így a regionális és a szervezeti kultúra között.

$\mathrm{Az}$ a tény, hogy a szervezetek nemcsak a részvényeseikkel, hanem a stakeholderekkel is számolnak, szintén érdeklődésre számot tartó téma. Heidbrink és Seele (2007) az ötödik elméleti összefoglalóban kifejtették, hogy a szervezetek ki vannak téve a stakeholderek befolyásának. ők azok az egyének és csoportok, akik hasznot látnak vagy károsodnak, akiknek a jogait megsértik vagy tiszteletben tartják a szervezetek a tevékenységük során. A vállalatoknak - társadalmi és gazdasági tevékenységük során - figyelembe kell venniük a tulajdonosokat, a részvényeseket és az érdekeltek különböző csoportjait (mint például a munkavállalók, a vásárlók, a menedzserek, a beszállítók, a helyi közösségek). Mindez azt jelenti, hogy a szervezetek az őket körülvevő társadalom polgárai, így felelősek a régióért, amelyben tevékenykednek, és e tevékenységükért számon kérhetők.

A hatodik elméleti alaptétel a „dilemmamegközelítés”. Prud'homme van Reine és Dankbaar (2007) nézete szerint a regionális és a szervezeti kultúra közti 
dinamikus kölcsönhatás vizsgálatához a dilemmaelmélet a megfelelő megközelítés. A dilemmaelmélet elismeri a kultúrák összetettségét, dinamikáját, valamint a belső kontroll és a külső környezethez való adaptáció ellentmondásosságát. Megállapításuk szerint a kulturális fejlődés a dilemmákkal való eredményes megbirkózással jöhet létre. A szervezetek és régiók hasonló dilemmákkal szembesülnek, mint például globális vagy lokális dilemmák, stabilitás vagy dinamikus változás, eredményorientáció vagy életminőség-orientáció, rövid vagy hosszú távú döntéshozatal.

Treinen (2007) a hetedik elméleti munkában azt a tényt elemzi, miszerint a régió és az ott működő üzleti világ közti kapcsolat ritkán egydimenziós. Számos olyan egymásba fonódó terület létezik, amelyekben a helyi, a regionális, a kormányzati és a vállalati intézmények formális és informális kommunikációja zajlik. Mindez azért lényeges a kutatás szempontjából, mert az interjúk megkezdése előtt indokolttá tette a regionális szereplők és a vállalatok közti közvetítés megteremtését (ezt a célt szolgálták a fókuszcsoportos beszélgetések).

\section{Kutatási kérdések és módszerek}

A nemzetközi kutatócsoport három kutatási kérdést fogalmazott meg, ezek az alábbiak:

- Milyen módokon hatnak egymásra vagy befolyásolják egymást a regionális és a szervezeti kultúrák?

- Miért elkötelezettek, illetve miért nem a vizsgált vállalatok?

- Milyen mértékben elkötelezettek a vállalatok a vizsgált négy területen?

A vállalatok és a régiók közti kulturális hatás vizsgálatára a kutatócsoport kvalitatív módszertant alkalmazott, elsősorban interjúkat. Az interjúk eredményeinek összehasonlíthatósága érdekében az interjúk félig strukturáltak voltak.

\section{A kutatás lépései}

Első lépés volt a régiók kiválasztása, majd a vállalatokról adatok összegyűjtése, továbbá a régió legfontosabb képviselőivel (önkormányzatok, ipari parkok, oktatási intézmények, kamarák, munkaügyi szervezetek stb.) szervezett nyitótalálkozó. A találkozón a megkérdezettek a négy fő kutatási területről (innováció, humán erőforrás, életminőség, társadalmi felelősség) osztották meg véleményüket a kutatókkal.

A második lépés a régiónkénti 30 vállalat kiválasztása volt. Lényeges volt, hogy a minta különböző vállalattípusokat tartalmazzon. Hat szempontot kellett figyelembe venni: tulajdonosi struktúra, földrajzi elhelyezkedés, idődimenzió, piacorientáció, klaszterhez tartozás és tudásintenzitás. Harmadik lépésként a 
vállalatokról kellett a lehető legtöbb információt összegyűjteni azok partnereitől, így a vállalati vezetők véleményét tükröző interjúkat külső szempontú adatokkal egészíthettük ki. Negyedik lépésben a 7×30 vállalati interjút bonyolítottuk le 2008 . április és október között, időtartamuk átlagosan 1-1,5 óra volt. Az interjúk alanya a vállalat tulajdonosa és/vagy vezető menedzsere volt. Az interjúk nyitottan és elbeszélő módon kezdődtek, majd a kulcsterületek kérdéscsoportjainak megválaszolásával folytatódtak. Az interjúkat legalább két fö bonyolította: a kérdező csak a válaszadóra figyelt, segítője jegyzetelt. A legalább két fö (több esetben három fö) részvétele azért is szükséges volt, mert számos esetben az interjúkészítőknek a válaszok alapján becsült értékeket kellett megadni, ez pedig megbízhatóan csak több nézőpont összevetésével volt lehetséges. Ötödik lépésként a kapott információkat értelmeztük és kódoltuk. A beszélgetés hangfelvételét egységes formátumban gépeltük le, az interjún részt vevő kutatók által pontosítva. Ezt követően - hatodik lépésként - elkészültek a regionális beszámolók. Jelen tanulmány a hét régió jelentései alapján készült (Dörhöfer, Minnig, Pekruhl 2009; Gärtner, Rehfeld 2009; Losoncz, Varga, Konczos 2009; Nussmueller, Lengauer, Tödtling 2009; Prud'homme van Reine, Dankbaar 2009; Treinen, Trippl, Tödtling 2009).

\section{A vizsgált régiók és vállalatok alapadatai}

A vizsgált vállalatokról az alábbi fontosabb megállapítások tehetők az öt dimenzió - földrajzi, tulajdonosi, idő, piaci és tudásintenzitás - szempontjából (vö. 1. táblázat).

A földrajzi dimenzió alapján a vizsgált vállalatok többsége (64\%) regionális jellegü, míg a tulajdonosi struktúra alapján családi tulajdonban van vagy részvénytársaság. A regionális léptékủ családi vállalatok száma a legjelentősebb a mintában (34\%), amelyekre a dolgozói lojalitás, a tolerancia, a konfliktusok nyílt megbeszélése a jellemző.

Az idődimenzió szempontjából kiegyensúlyozottság figyelhető meg: közel azonos számban vannak a 20 évnél idősebb (70), a 10-20 év közötti (63) és a 10 évnél fiatalabb (77) vállalatok a mintában.

1. táblázat: A vizsgált vállalatok adatai

Main data of the investigated companies

\begin{tabular}{lcccc}
\hline \multirow{2}{*}{ Tulajdonosi struktúra } & \multicolumn{4}{c}{ Földrajzi dimenzió } \\
\cline { 2 - 5 } & Regionális & Nemzeti & Nemzetközi & Összesen \\
\hline Részvénytársaság & 46 & 17 & 36 & 99 \\
Családi vállalkozás & 73 & 10 & 8 & 91 \\
Önkormányzati tulajdonú vállalkozás & 16 & 3 & 1 & 20 \\
\hline Összesen & 135 & 30 & 45 & 210 \\
\hline
\end{tabular}

Forrás: CURE regionális összefoglalók. N=210, de a nem mindig teljes körü válaszok miatt eltérések lehetnek. 
Jellemző a nemzetközi piaci orientáció (90 vállalat, 50\%), melyet a közel azonos súllyal a nemzeti ( $42 \mathrm{db}, 23 \%$ ) és regionális ( $48 \mathrm{db}, 27 \%$ ) piacokon jelen levő vállalatok követnek. A nemzetközi jelenlét magas aránya a globalizáció hatását mutatja, az erőfeszítéseket a külföldi piacok felé történő nyitásra.

A tudásintenzitás jellemzésére két kategóriát használtunk: magas és alacsony tudásintenzitás, amelyet az interjúalanyok határoztak meg. A vizsgált vállalatok 65\%-a (137 db) mondta magáról, hogy magas tudásintenzitás jellemzi, mert csak így tudják túlélni a globális versenyt.

Összességében azt mondhatjuk, hogy a fiatal, regionális, tudásintenzív, nemzetközi piaci orientációjú családi vállalkozások a jellemzők a vizsgált régiókban.

A mintában gyakoriak a relatíve nagynak tekinthető vállalatok is, de a kis- és középvállalatokból több szerepelt. Az esettanulmányok eltérő tipológiát használtak a vállalakozások méretéről, így jelen tanulmányban csak két kategóriát alkalmaztunk: a kkv-kben kevesebb, mint 250 fö, a nagy és nagyon nagy vállalatokban 250 főnél több alkalmazott dolgozik. Előbbi csoportba 101, utóbbiba 83 vállalat tartozott (több regionális jelentésben nem szerepelt a vállalat nagysága).

Az iparágakat tekintve számos ágazat mondható tradicionálisnak az egyes régiókban, de ezek mellett új ágazatok is rohamos gyorsasággal növekszenek (2. táblázat).

2. táblázat: A régiókban domináns iparágak

The dominant industries in the selected regional economics

\begin{tabular}{ll}
\hline \multicolumn{1}{c}{ Régió } & \multicolumn{1}{c}{ Domináns iparágak } \\
\hline Győr környéke (Magyarország) & Autóipar, gépipar \\
Délkelet-Hollandia & High-tech rendszerek, autóipar, élettudományok \\
Bázel környéke (Svájc) & Vegyipar és gyógyszergyártás \\
Kelet-Vesztfália / Lippe (Németország) & Design, média, egészségipar \\
Délnyugat-Brandenburg (Németország) & Biotechnológia, lakásszektor \\
Stájerország (Ausztria) & Fémipar, autógyártás, szoftveripar \\
Wales (Egyesült Királyság) & Pénzügyi szektor, élelmiszeripar, biotechnológia, \\
& repülőgép- és hajógyártás \\
\hline
\end{tabular}

Forrás: CURE regionális összefoglalók.

\section{Eredmények}

A következőkben a négy vizsgált kérdéscsoport alapján összegzem, mennyire fontosak a régiók a megkérdezett vállalatok számára, valamint hogyan hatnak a vállalatok a régiókra - például mennyire integrálódtak gazdaságilag a régióba, mennyire befolyásolják a régiót üzleti tevékenységükkel és regionális fontosságú ügyek támogatásával. Továbbá megvizsgálom az elköteleződés, illetve az elköteleződés hiányának okait. 


\section{A vállalatok regionális elköteleződése a négy vizsgált tématerületen}

A kutatás a régióknak a vállalatok számára jelentett szerepét vizsgálta az innováció, a humán erőforrás, a fenntarthatóság és az életminőség területén. (3. táblázat).

A humán erőforrás szempontjából a régiók „nagyon fontos” és „fontos” értékelést kaptak. Ez szorosan összefügghet azzal a ténnyel, hogy egy vállalatnak az adott régióban való letelepedését erősen befolyásolja a képzett és motivált munkaerő megléte.

A regionális innováció megkérdőjelezhetetlen fontossága a magas tudásintenzitású vállalatokat jelzi a vizsgált régiókban; a cégek nagy jelentőséget tulajdonítanak az innovációnak versenyképességük megtartásában (amikor a versenyelőnyt biztosító hagyományos források - pl. az olcsó munkaerő - már kimerültek).

3. táblázat: A régió jelentősége a vállalatok számára Importance of the region for the companies

\begin{tabular}{lcccc}
\hline \multicolumn{1}{c}{ Tématerület } & Nagyon fontos & Fontos & Alig fontos & Nem fontos \\
\hline Innováció & 29 & 42 & 37 & 37 \\
Humán erőforrás & 59 & 48 & 37 & 16 \\
Fenntarthatóság & 28 & 32 & 46 & 53 \\
Életminőség & 25 & 52 & 44 & 20 \\
\hline A régió összességében & 32 & 62 & 35 & 4 \\
\hline
\end{tabular}

Forrás: CURE regionális összefoglalók. N=210, de a nem mindig teljes körü válaszok miatt eltérések lehetnek.

A régió által kínált magas életminőség szorosan összefügg a felsőmenedzsment és családjuk régióban való jelenlétével. Nagyra értékelik az adott régió által nyújtott kellemes természeti és kulturális környezetet, amelyek hozzájárulnak a megfelelő életminőség biztosításához.

Annak ellenére, hogy a természeti környezet szabályozása egyre szigorúbb, továbbá a lakosság is egyre érzékenyebb a fenntarthatóságra, meglepő módon a vizsgált vállalatok körében a régió szerepe a fenntarthatóságban az „alig fontos” és a „nem fontos” megítélést kapta. A régió szerepét összességében fontosnak ítélték a megkérdezettek a vizsgált négy tématerületen.

Ha a vállalatok régióik iránti elkötelezettségét vizsgáljuk (4. táblázat) - az interjúkészítők és a kutatás első lépésében szerzett információk alapján -, a vizsgált vállalatok többsége leginkább az innováció, a humán erőforrás és az életminőség iránt elkötelezett. Ez megegyezik azzal, ahogy a régiók fontosságát megítélték. A vállalati felelősségvállalás számos esetben áthatja a vállalatok teljes irányítását és fenntarthatóságért folytatott tevékenységét: befolyásolja és áthatja a teljes stratégiát és müködést (Ridley, D'Silva, Konczos 2011). Ez a vállalati viselkedés hatással van a szervezet hírnevére és a "vállalati jó polgárság” legfőbb bizonyítékának tekinthető. 
4. táblázat: A vállalatok elkötelezettsége a vizsgált területeken (becslés) Estimations of the regional engagement of the companies

\begin{tabular}{lcccc}
\hline Tématerületek & $\begin{array}{c}\text { Erősen elkötelezett: } \\
\text { kezdeményező és } \\
\text { keretet adó }\end{array}$ & $\begin{array}{c}\text { Elkötelezett: } \\
\text { szponzor és } \\
\text { támogató }\end{array}$ & $\begin{array}{c}\text { Alig elkötelezett: } \\
\text { adófizető tag }\end{array}$ & Nem elkötelezett \\
\hline Innováció & 45 & 50 & 48 & 31 \\
Humán erőforrás & 40 & 65 & 46 & 29 \\
Fenntarthatóság & 20 & 55 & 53 & 53 \\
Életminőség & 38 & 72 & 38 & 33 \\
\hline A régió összességében & 35 & 89 & 43 & 13 \\
\hline
\end{tabular}

Forrás: CURE regionális összefoglalók. $N=210$, de a nem mindig teljes körü válaszok miatt eltérések lehetnek

A vállalatok közel 40\%-a viszont e három terület iránt nem vagy alig mutat elkötelezettséget. Továbbá a vállalatok többsége (közel 60\%) alig elkötelezett vagy nem elkötelezett a fenntarthatóság iránt.

Szoros kapcsolat mutatható ki a régiók fontosságának megítélése és a vállalatok regionális elköteleződése között: azok a vállalatok a legelkötelezettebbek a régiók iránt, amelyek számára a régió fontos a vizsgált területeken.

\section{A vizsgált vállalatok tipológiája}

A vállalatokat az elköteleződés hiányától a teljes elkötelezettségig kategorizáltuk, a besorolás az interjút végző kutatócsoportok becslésével történt. Ehhez figyelembe vettük a projektindító találkozók résztvevőinek véleményét, az adott vállalatokról gyűjtött és az interjúk során szerzett információkat.

Az első kategória az „elfogadó”, amelybe 38 vállalat tartozik. A cégeknek ez a típusa nem érdeklődik a régió iránt, amelyben működik. A második típus az „ügyfél” (35 vállalat), ők befizetett adójukért cserébe ellenszolgáltatást is várnak a régiótól, közvetlen vagy közvetett módon. A vállalatok harmadik típusa a „látogató" (38 cég): ők bizonyos ideig a régióban maradnak, és jobban érdeklődnek a régió és annak fejlődése iránt, mint az előző típus. Élvezik a régió nyújtotta előnyöket, de viszonozzák is azt: bizonyos regionális ügyeket, intézményeket, fejlesztéseket támogatnak (pl. kulturális rendezvényeket, a helyi infrastruktúra fejlesztését), amíg a régióban vannak. A régió iránt legelkötelezettebb vállalatok a ,jó polgárok" (69 vállalat), amelyek teljesen beágyazottak a régióba. Magukat a régió részének tekintik, és részt vesznek a régiót érintő főbb döntések meghozatalában. Az adófizetésen túl számos regionális tevékenységet és szervezetet támogatnak. Hosszú távon a régióban maradást tervezik, ezért érdekeltek a régió fejlesztésében, a jólét megteremtésében, az életminőség és az innovációs potenciál növelésében.

Nagyon fontos megjegyezni, hogy az utolsó csoportba nemcsak a mélyen beágyazott helyi vállalkozások tartoznak, hanem jó néhány külföldi vállalat is: a 
helyi menedzsment régióba való beágyazottsága és a régió iránti felelősségvállalás a hosszú távú elkötelezettséget jelenti. A globalizáció ugyanakkor gyengítő hatással is lehet a régió és a multinacionális vállalatok együttmüködésére. Némely kutatók „otthontalan” és „gyökértelen” cégekről beszélnek - ezek olyan multinacionális vállalatok, amelyek nem kötődnek egy régióhoz vagy országhoz, hanem ott hoznak létre létesítményeket, ahol épp legkedvezőbbek a feltételek az adott időszakban, majd bezárják azokat és továbbmennek, amint máshol kedvezőbb lehetőségek adódnak. A vizsgált vállalatok között 40\% nem vagy alig integrálódott, jelentős részük az otthontalan, gyökértelen jelzőkkel illethető.

\section{A regionális elkötelezettség és el nem kötelezettség okai}

A kutatócsoport tagjai megpróbálták azonosítani a vizsgált vállalatok etikai orientációját, vagyis hogy a társadalmi és regionális elkötelezettséggel kapcsolatos döntéseiket üzleti, etikai vagy vegyes indíttatásból hozzák-e.

A vizsgált vállalatok megközelítően 20\%-a (41 db) kizárólag üzleti alapon hozza meg a döntéseit, etikai orientáció nem szerepel a szempontjaik között. A vállalatok több mint fele (106 vállalat) kombinálja a két szempontot. A vállalatok 20\%-a (42 db) döntéseiben ragaszkodik az etikai aspektusokhoz (több regionális jelentésben nem szerepelt a vállalat etikai értékelése). Tehát összességében a megkérdezett vállalatok közel 80\%-a veszi figyelembe az erkölcsi szempontokat (is) az elkötelezettséggel kapcsolatos döntései során.

Az interjúkban számos érv hangzott el az elkötelezettség, illetve az elkötelezettség hiányának indokaként. Az elkötelezettség okait közvetlen és közvetett tényezők alkotják. A közvetlen tényezők miatt elkötelezett vállalatokat a gazdasági haszon és az üzleti szempont motiválja. Közöttük vannak olyanok, amelyek napi kapcsolatban vannak a lakossággal (pl. kommunális szolgáltatók), mások ingatlanokba, technológiákba stb. fektettek be, további csoportjuk bizonyos képzettségű és képességü munkaerő iránt érdeklődik. A klaszterek támogatása, a beszállítói láncokhoz, különböző hálózatokhoz, szakmai szervezetekhez (pl. kamarák) való tartozás is gazdasági okkal magyarázható.

A vállalatok másik csoportjának motivációja közvetett, nem gazdasági tényezőkre vezethető vissza: a kulturális események vagy civil szervezetek támogatása, kezdeményezések, szakmai szövetségek, helyi egyetemek és oktatási intézmények pénzügyi támogatása sokkal inkább etikai motivációjú, mintsem üzleti. „A vállalatvezetők vagy vállalkozók személyes motivációit gyakran említik mint a régió iránti elkötelezettség okát. Sőt, a kis cégek esetében a tulajdonost/igazgatót nagyon erős és meghatározó kötelékek füzik a régióhoz, és ezért gyakran erős érzelmi kapcsolata van vele." (Nussmueller, Lengauer, Tödtling 2009, 41.) A tulajdonosok és a menedzserek regionális elköteleződése erkölcsi parancs számukra. „Érdekes módon, ha a vállalatok elkötelezettek a társadalmi ügyek iránt, mint például a mozgáskorlátozottak munkavállalásának támogatása vagy a gyermeküket egyedül nevelő anyák 
anyagi támogatása, ezt nem üzleti megfontolásból teszik. Ez sokkal inkább magyarázható emberbaráti érzelmekkel." (Nussmueller, Lengauer, Tödtling 2009, 45.)

A régió iránti elkötelezettség hiánya is sokféle okra vezethető vissza. A közös ezekben az okokban a gazdasági érdek. A globális verseny óriási erőfeszítést követel meg a cégektől, de a pénzügyi korlátok is fontos megszorító tényezők. Emellett bizonyos cégek partnerköre nagyon kicsi, többségük gyakran kívül esik a régión, ezért nem érdekük a társadalmi szerepvállalás, a helyi törekvések támogatása. E cégektől kapott tipikus válaszok: „A cég számos rendezvényt és oktatási intézményt támogat, de üzleti kapcsolatai alapvetően nagyon szűkek: főleg a többi leányvállalattal és három fö üzleti partnerrel.” „Nagyon kicsi önállósággal rendelkezünk.” „Nincs potenciális ügyfél a régióban.” stb.

A társadalmi tőke fontos fogalommá vált az elmúlt évtized menedzsmentirodalmában. A társadalmi tőke a stakeholderek bizalmának és megértésének a kifejeződése a vállalat iránt. „A társadalmi tőke a valódi gazdaság világában egyfajta belépőjegy az üzleti életbe" (Cooke, Clifton, Oleaga 2005).

A társadalmi és szakmai hálózatokban való részvétel a legjobb útja a vállalatok számára a társadalmi tőke megszerzésére a régióban. Az általános társadalmi tőkét pedig a jó polgársággal (szponzorálás, önkéntesség, támogatás), társadalmi felelősségvállalással (regionális foglalkoztatás, fenntartható termelés, jó vállalatirányítás, tisztességes kereskedelem, esélyegyenlőség biztosítása) is növelhetik (Dörhöfer, Minnig, Pekruhl 2007, 26.).

Számos külföldi tulajdonú cégnél a menedzsment és a kulcsfontosságú területeken dolgozó személyzet a régióból származik. A vizsgált magyarországi cégekben a menedzsment és a kulcsfontosságú munkatársak 80\%-a Győrben és annak $50 \mathrm{~km}$-es vonzáskörzetében él; a 40 menedzserből 36 a régióban él; a kulcspozíciók mindegyikét - egy osztrák ügyvezető kivételével - magyarok töltik be; a 4 igazgatóból 3 helyi.

$\mathrm{Ha}$ az emberek azonos régióban és azonos iskolarendszerben nőnek fel, akkor azonos regionális mentalitásuk alakul ki. Ez a kulturálisan megalapozott regionális mentalitás olyan területeken nyilvánul meg, mint például a kommunikációs stílus, a pénzhez való attitűd, a munkaetika. A regionális hagyományokban szocializálódott emberek behozzák a vállalatukba hagyományos értékrendjüket. Ez esetben beszélhetünk a „személyzet mint szállítójármü” jelenségéről (Dörhöfer, Minnig, Pekruhl 2007, 14-17.).

„Ahogy az várható, a multinacionális vállalatok leányvállalatai gyakran nem kötődnek elég erősen a helyi ügyekhez. Általában véve elég kicsi önállóságuk van a döntéshozatalban, és a rendszerint más országban levő anyavállalat nem is nagyon bátorítja őket a régióban való aktív szerepvállalásra. Ugyanakkor ha a leányvállalatok innovatívak és alkalmazzák a tudományos ismereteket, akkor rendszerint erős hálózatokat építenek ki a helyi tudásszolgáltatókkal." (Nussmueller, Lengauer, Tödtling 2009, 41.)

A régióba integrálódott vállalatok profilja és háttere különféle lehet. Azok a vállalatok, amelyeknek a története több mint 100 évre nyúlik vissza, valamint 
a fiatal vállalkozások egyaránt nagyon erősen tudnak integrálódni a régióba. Ebben nincs különbség a családi vállalkozások és a részvénytársaságok között, továbbá mind a külföldi, mind a hazai menedzserek aktívan részt tudnak venni a helyi társadalmi életben. A régióba integrált vállalatok felelősséget éreznek nemcsak dolgozóikért és üzleti partnereikért, hanem a régióért általában is. „Noha a termék- és szolgáltatáshálózatok nagyon fontosak, a társadalmi hálók szerepe és fontossága egyre nagyobb érdeklődésre tart számot mind a gyakorlat, mind a tudomány képviselőitől. A szövetség létrehozásának képessége roppant fontos (szakmai) kompetencia." (Dörhöfer, Minnig, Pekruhl 2007, 18-19.)

\section{Következtetések}

A tanulmány megpróbálta feltárni a régiók és a vállalatok közti kulturális kölcsönhatást. A regionális és a szervezeti kultúrák erősen összefonódnak, kölcsönösen hatnak egymásra, de nem azonos módon. A „hogyan” többé-kevésbé fekete doboz marad. Az egyének egyszerre tagjai mind a regionális, mind a szervezeti kultúrának. Saját regionális kultúrájukkal hatást gyakorolnak a szervezeti kultúrákra, ezért a kétféle kultúra közti csere járművének lehet őket nevezni.

A szervezeti kultúrák erős hatással lehetnek a környezetükre, így a régióra is. Vizsgálatunkban ugyanakkor azt tapasztaltuk, hogy a regionális kultúrának jelentős hatása van a szervezeti kultúrára, amiben a régióban gyökerezett menedzsereknek jelentős szerepük van, ugyanis egyéni kapcsolataik meghatározók a társadalmi és szakmai hálózatokban. Ezek a kapcsolatok növelhetik a vállalatok társadalmi tőkéjét és a vállalat imázsát. Vagyis az emberi tőke az egyik legfontosabb vállalati érték a beágyazódásban is.

Az eredmények az eleven, innovatív és sokszínű régiókkal rendelkező Európa fejlődésére számos érdekes példát és ötletet mutatnak. Világossá vált a kutatás során, hogy a regionális kultúrák nem változtathatók szándékosan, hiszen hosszú távon hatnak, mélyen gyökereznek az egyéni és a kollektív tudatban, ugyanakkor heterogének és dinamikusak. Az is világossá vált, hogy a kultúrák meghatározó szerepet játszanak az életminőségben, a gazdasági szereplők térbeli elhelyezkedésében és ezzel együtt a régiók versenyképességében, a kulturálisan sokszínű Európa lehetőségeinek formálásában.

A kultúra befolyása fontos lépés a régiók egyediségének megteremtésében, ami jelentős hasznot jelenthet az ott működő vállalatoknak. Ezt felismerve a kutatás egyik meglepő eredménye, hogy a globális piacon szereplő multinacionális vállalatok felismerték ezt a versenyelőnyt, és - az előfeltételezésekkel ellentétben, miszerint a világpiacban gondolkodva nem lojálisak a régiókhoz - döntő többségük a régiók iránt mélyen elkötelezett, sőt társaikat meghaladóan vállal felelősséget a régió iránt, például a regionális hálózatok támogatásában. Erre volt bizonyíték a ,jó polgár" kategóriájú és az elkötelezett vállalatok nagy száma. 
A vállalatok elkötelezettségének, illetve az elkötelezettség hiányának számos okát tárta fel a kutatás. Az esetek többségében a regionálisan elkötelezett, beágyazott vállalatok sikeresebbek. Ez a siker olyan tényezőkkel magyarázható, mint a lelki/szellemi közelség, a dolgozók, a régió, a környezet iránti felelősség, vagyis mindazok a tényezők, amelyeket a klasszikus piacelméletek figyelmen kívül hagynak, és amelyek hagyományos elemzési módszerekkel nem kimutathatók. Az innováció, az életminőség és a humán erőforrás a régió és a vállalat számára is fontos tényező. Ugyanakkor számos vállalat sem regionálisan, sem globálisan nem mutat felelős magatartást. Meglepő eredmény a fenntarthatóság kérdéskörének számukra csekély fontossága.

A gazdasági válság lehetőséget ad arra, hogy a hagyományos gazdasági dogmák helyett megvitassuk a vállalatok társadalmi és regionális beágyazottságának és felelősségének kérdését, az állam szerepét és Európa regionális sokszínüségének fontosságát.

\section{Köszönetnyilvánítás}

A CURE projektet az Európai Bizottság az FP6 NEST célkitűzés keretében támogatta (szerződésszám: 043438).

\section{Irodalom}

Ablonczyné Mihályka L., Tompos A. (2011a): Az OPTICOM projekt kutatási tevékenységeinek bemutatása. In: Borgulya Á., Deák Cs. (szerk.): Vállalati kommunikáció a 21. század elején. Z-Press Kiadó, Miskolc, 287-294.

Ablonczyné Mihályka L., Tompos A. (2011b): Osztrák üzleti kultúra magyar szemmel. Porta Lingua, 225-230.

Asheim, B. (2000): Industrial districts: The contributions of Marshall and beyond. In: Clark, G., Feldman M., Gertler, M. (eds.): The Oxford handbook of economic geography. Oxford University Press, Oxford, 413-431.

Boekma, F., Morgan, K., Bakkers, S., Rutten R. (eds.) (2000): Knowledge, innovation and economic growth: the theory and practice of learning regions. Edward Elgar, Cheltenham

Cameron, K., Quinn, R. E. (2006): Diagnosing and changing organisational culture. Based on the competing values framework. Jossey-Bass, San Francisco

Clifton, N. (2009): Regional report. D26 Wales, CASS, Cardiff University

Cooke, P. (2002): Knowledge economies. Clusters, learning and cooperative advantage. Routledge, London

Cooke, P., Boekholt, P., Todtling, F. (2000): The governance of innovation in Europe. Pinter, London

Cooke, P., Clifton, N., Oleaga, M. (2005): Social capital, firm embeddedness and regional development. Regional Studies, 8., 1065-1077.

Cooke, P., Heidenreich, M., Braczyk, H. J. (2004): Regional innovation systems. 2nd edition. Routledge, London

Crevoisier, O. (2004): The innovative milieus approach: toward a territorialized understanding of the economy? Economic Geography, 4., 367-379. 
David, A., Gärtner, S., Rehfeld, D. (2007): Regional images. Unpublished project paper. In: Interdisciplinary cultural issues. D8 Corporate and regional cultures and their interactions

Dörhöfer, S., Minnig, C., Pekruhl, U. (2009): Regional report Basel-area D29, In: Regional report on empirical analyses in Switzerland, University of Applied Sciences, North Western Switzerland

Florida, R. (2005): Cities and the creative class. Routledge, New York, London

Gertler, M. (2004): Manufacturing culture. The institutional geography of industrial practice. Oxford University Press, Oxford

Gärtner, S., Rehfeld, D. (2009): D24 Regional report East Westphalia Lippe

Hampden-Turner, C., Trompenaars, F. (2000): Building cross-cultural competence. John Wiley \& Sons, Chichester

Heidbrink, L., Seele, P. (2007): Who responds to whom? Unpublished project paper. In: Interdisciplinary cultural issues. D8 Corporate and regional cultures and their interactions

Hofstede, G., Hofstede, G. J., Minkov, M. (2004): Cultures and organizations: software of the mind. McGraw-Hill, New York

Huszka P. (2010): Az egészségmagatartás néhány elemének vizsgálata primer kutatatás alkalmazásával. In: V. KHEOPS Tudományos Konferencia „Útkeresés a gazdasági válság nyomán”. Mór, 46-59.

Huszka P. (2012): Az egészségmagatartás néhány elemének vizsgálata primer kutatás alkalmával. Egészségfejlesztés, 5-6., 14-25.

Kebir, L., Crevoisier, O. (2007): Resources development and actors coordination: what role for innovative milieus? International Journal of Entrepreneurship and Innovation Management, 2., 204-222.

Keeble, D., Wilkinson, F. (eds.) (2000): High-technology clusters, networking and collective learning in Europe. Ashgate, Aldershot

Konczosné Szombathelyi M. (2009a): A vállalatok beágyazódottságának szerepe a válság tükrében egy EU-projekt alapján. In: Losoncz M., Solt K., Szigeti C., (szerk.): Kautz Gyula Emlékkötet. Széchenyi István Egyetem, Győr, 203-209.

Konczosné Szombathelyi M. (2009b): Egy EU projekt, mint az interkulturális kommunikáció példája. In: Kukorelli K. (szerk.): Hatékony nyelvi, idegen nyelvi és szakmai kommunikáció interkulturális környezetben. XI. Dunaújvárosi Nemzetközi Alkalmazott Nyelvészeti és Kommunikációs Konferencia, Dunaújvárosi Főiskola, Dunaújváros, 162-167.

Konczosné Szombathelyi M. (2009c): A kapcsolati marketing szerepe a vállalatok elismertségében egy EU-projekt tapasztalatai alapján. In: Szakály Z. (szerk.): Új marketing kihívások a XXI. században - Fenntartható fogyasztás. Magyar Marketing Szövetség Marketing Oktatók Klubja 15. Jubileumi Országos Konferencia Proceedings. Kaposvári Egyetem, Kaposvár, 1-8.

Konczosné Szombathelyi M. (2010a): Nemzetközi projekt a régiók együttműködéséért. In: Beszteri B., Majoros P., Zimler T. (szerk.): Magyarország határ menti térségeinek és városainak fejlödése a rendszerváltás és európai uniós tagságunk következtében. A 2010. április 27-én Komáromban rendezett tudományos konferencia előadásai. MTA VEAB, BGF, Széchenyi István Egyetem, Komárom, Veszprém, 225-234.

Konczosné Szombathelyi M. (2010b): Az innováció szerepének vizsgálata egy EU projekt eredményei kapcsán. In: Lőrincz I. (szerk.): XIII. Apáczai-napok 2009 nemzetközi tudományos konferencia „Kreativitás és innováció” tanulmánykötet. NYME ACSJK, Győr, 297-304.

Konczosné Szombathelyi M. (2011): Személyes kötődés és szervezeti beágyazódottság. In: Lőrincz I. (szerk.): Európaiság, magyarság Közép-Európában. XIV. Apáczai-napok Nemzetközi Tudományos Konferencia 2010. NYME ACSJK, Győr, 484-491.

Konczosné Szombathelyi M., Losoncz M., Józsa L. (2010): Managerial rules beyond the regional embeddedness: a study of European companies. In: Ogunmokun, G., Gabbay, R., Rose, J. (eds.): 4th Biennal Conference of Academy of World Business, Marketing and Management Development, Conference proceedings, 850-866.

Losoncz M., Varga K., Konczos M. (2009): Regional report D25. Széchenyi István University, Győr

Martin, R., Sunley, P. (2003): Deconstructing clusters: chaotic concept or policy panacea? Journal of Economic Geography, 1., 5-35.

Nussmueller, E., Lengauer, L., Tödtling, F. (2009): Deliverable: D30 CURE - Regional report - Styria. Vienna University of Economics and Business Institute for the Environment and Regional Development, Vienna 
Pekruhl, U., Minning, C., Dörhöfer, S. (2008): Cultural interchange between regions and companies. Unpublished project paper

Prud'homme van Reine, P., Dankbaar, B. (2007): Corporate culture, regional culture and change from the cross-cultural management discipline. Cure project deliverable 5

Prud'homme van Reine, P., Dankbaar, B. (2009a): WP4 Deliverable D28, Regional report, Southeast Netherlands: Radboud Universiteit, School of Management, Nijmegen

Rechnitzer J., Lengyel I. (2004): Regionális gazdaságtan. Dialóg Campus Kiadó, Budapest, Pécs

Ridley, J., D'Silva, K., Konczos, M. (2011): Sustainability assurance and internal auditing in emerging markets. Corporate Governance, 4., 475-488.

Rodrigez-Pose, A. (2001): Killing economic geography with a "cultural turn" overdose. Antipode, 2., 176-182.

Süle E. (2010): Az idő - mint az egyik legfőbb logisztikai hasznosság - társadalmi és gazdasági értékelése. In: Egri I., Földesi P., Szegedi Z. (szerk.): Logisztikai antológia. Universitas-Győr Nonprofit Kft., Stúdium Kiadó, Győr, 217-239.

Szőke J., Ablonczyné Mihályka L. (2011): Culture's strategic role in SMEs' cross-border relations. Strategic Management: International Journal of Strategic Management and Decision Support System in Strategic Management, 4., 23-28.

Tompos A., Ablonczyné Mihályka L. (2011): Kritikus interakciós esetek: magyar adatközlők osztrák üzleti partnereikről. In: Lőrincz I. (szerk.): Európaiság, magyarság Közép-Európában XIV. Apáczainapok Nemzetközi Tudományos Konferencia 2010. NYME ACSJK, Győr, 93-101.

Tödtling, F., Trippl, M., (2007): Regional innovation culture. Cure project deliverable 6.

Treinen, H. (2007): Frame-analysis. Unpublished project paper.

Treinen, H., Trippl, M., Tödtling F. (2009): Regional report D27 - Brandenburg Southwest (Germany). KWI Institute for Advanced Studies in the Humanities, Essen

Tura, T., Harmaakorpi, V. (2005): Social capital in building regional innovative capability. Regional Studies, 8., 1111-1125. 